\title{
Excess of cancer deaths in grandparents of patients with retinoblastoma*
}

\author{
C BONAÏTI-PELLIÉ $†$ AND M L BRIARD-GUILLEMOT+
}

From the †Groupe de Recherches de Génétique Epidémiologique, INSERM, Château de Longchamp; and $\ddagger$ Unité de Recherches de Génétique Médicale, INSERM, Hôpital des Enfants-Malades, Paris, France

SUMMARY An excess of cancer deaths was found in grandparents of 308 children with retinoblastoma. This excess was found in all types of retinoblastoma, unilateral and bilateral, sporadic and familial. We postulated that the excess could be the result of a factor of susceptitility to cancer, different from the retinoblastoma gene, which would increase the mutation rate in retinal and germ cells as well as in other tissues.

The genetic factors in retinoblastoma have been well analysed. The two-mutational process ${ }^{1}$ allows an overall explanation of the heterogeneity of the affection. When the disease is bilateral, a germ cell mutation is the primary event and is expressed in the heterozygous state with a manifestation of almost $100 \%$, as the result of a second somatic mutation in several retinoblasts. A small fraction of unilateral cases have the same origin, the somatic mutations having occurred by chance in a single eye. The majority of these unilateral cases is represented by phenocopies which are the result of two successive somatic mutations.

Children have been shown to develop second primary cancers with a much higher frequency than controls. ${ }^{2-6}$ These tumours may be radiation-induced or non-radiogenic. Among non-radiogenic tumours, a high frequency of osteogenic sarcomas in long bones has been found. In most children who develop a second tumour, the retinoblastoma is bilateral. Strong and Knudson ${ }^{4}$ suggested that the gene for retinoblastoma might be on the pathway to tumour formation in some tissues, in which case a second mutation would initiate a second-site tumour. Kitchin and Ellsworth ${ }^{5}$ reached the same conclusion; they believed that the retinoblastoma locus could be related to the DNA polymerase enzyme systems.

Weichselbaum et $\mathrm{al}^{\mathbf{7}} \mathbf{8}$ found increased fibroblast radiosensitivity in a patient with retinoblastoma associated with a chromosome 13 deletion. Fibroblasts in patients with familial retinoblastoma

*Supported by a grant from Institut National de la Santé et de la Recherche Medicale (INSERM), Paris, France, ATP No 76.68 .

Received for publication 4 July 1979 showed significantly higher radiosensitivities than fibroblasts derived from patients with sporadic retinoblastoma, the latter being within the normal range. The authors postulated the existence of a DNA repair defect in hereditary cases to account for the high incidence of second tumours in these patients.

Some families with a particular high frequency of cancer in relatives have been published. ${ }^{9-11}$ Fedrick and Baldwin ${ }^{12}$ found a significant excess of cases of cancer in relatives of nine patients.

The purpose of this study is to compare the number of cancer deaths of grandparents of retinoblastoma patients in our large series ${ }^{13}$ to the expected number, based on French mortality statistics. Grandparents were chosen rather than parents since most of the latter are still alive. Data on other relatives were incomplete and so susceptible to bias.

\section{Material}

Our material has been collected from multiple sources: hospitals, private ophthalmologists, radiotherapists, ocularists, anatomopathologists, and schools for visually handicapped children, from various regions of France. A complete family history could be obtained for 598 patients at the time of publication and 28 new patients, most often by interview with the mother or father or the proband himself, and in some instances by postal questionnaire. Families were regularly followed up and asked for additional information, in particular concerning births or deaths of the different family members. However, the dates and causes of death were not recorded for all grandparents. In some 
families, it was not possible to complete the data, because the parents could not be found, or they were uncooperative, or they were too upset by the death of their children. To the 246 others, we sent questionnaires asking the dates of birth and, when relevant, the dates and causes of death of the four grandparents. Enclosed was a list of possible causes of deaths in order to elicit a maximum of correct answers. Responses to 167 questionnaires were received. No replies were received from 73 ; six questionnaires were returned address unknown. We could not use death certificates, as did Swift et al, ${ }^{14}$ because these certificates are anonymous in France.

Finally, 308 probands had at least one dead grandparent for whom the date, age, and cause of death were known. Subjects who were known to have cancer but died of another cause were counted as not cancer.

\section{Methods}

The expected number of deaths through cancer was calculated separately for grandfathers and grandmothers for each 10-year age group and each 5-year period from 1925 to 1977, inclusive, using the proportion of deaths from cancer in the French population (table 1) for each of these sex and age- $\curvearrowright$ period groups. The mortality statistics for France के before 1925 are not precise enough, so we did not $\vec{\circ}$ study deaths which occurred before this date. French statistics for 1976 and beyond are not yet $\vec{\omega}$ available, so we chose the values of the year 1975 ? for the period 1975 to 1977 . The data for the years 1937 to 1939 were not published because $\vec{\nabla}$ of disorganisation of French public services by iv the war, so we estimated the proportions by extra- of polation.

TABLE 1 Proportion of cancer deaths (\%) from malignant neoplasms in the French population

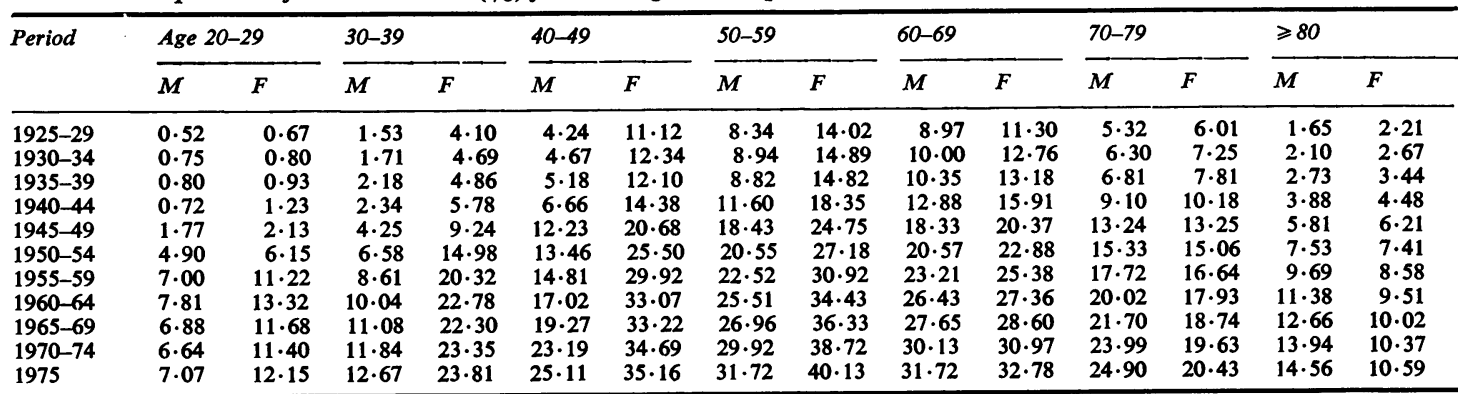

Sources: 1925-1967, INSEE, Statistique des causes de décès;

1968-1975, INSERM, Statistique des causes médicales de décès.

TABLE 2 Distribution of deaths of grandfathers of retinoblastoma probands

\begin{tabular}{|c|c|c|c|c|c|c|c|c|c|c|c|c|c|c|c|c|c|c|c|c|c|c|}
\hline \multirow[t]{2}{*}{ Date } & & \multicolumn{3}{|c|}{ Age 20-29 } & \multicolumn{3}{|c|}{$30-39$} & \multicolumn{3}{|c|}{$40-49$} & \multicolumn{3}{|c|}{$50-59$} & \multicolumn{3}{|c|}{$60-69$} & \multicolumn{3}{|c|}{$70-79$} & \multicolumn{3}{|c|}{$\geqslant 80$} \\
\hline & & $U S$ & $B S$ & Fam & $U S$ & $B S$ & Fam & $U S$ & $B S$ & Fam & $U S$ & $B S$ & Fam & $U S$ & $B S$ & Fam & $U S$ & $B S$ & Fam & $U S$ & $B S$ & Fam \\
\hline 1925-29 & $\begin{array}{l}\text { TD } \\
\text { CD }\end{array}$ & & $\begin{array}{l}1 \\
0\end{array}$ & & & & & $\begin{array}{l}1 \\
0\end{array}$ & & $\begin{array}{l}1 \\
0\end{array}$ & $\begin{array}{l}2 \\
1\end{array}$ & $\begin{array}{l}1 \\
0\end{array}$ & $\begin{array}{l}1 \\
1\end{array}$ & $\begin{array}{l}1 \\
0\end{array}$ & & $\begin{array}{l}1 \\
0\end{array}$ & $\begin{array}{l}1 \\
0\end{array}$ & & & & & \\
\hline 1930-34 & $\begin{array}{l}\text { TD } \\
\text { CD }\end{array}$ & & & & $\begin{array}{l}1 \\
0\end{array}$ & $\begin{array}{l}1 \\
0\end{array}$ & & $\begin{array}{l}5 \\
0\end{array}$ & $\begin{array}{l}2 \\
0\end{array}$ & & $\begin{array}{l}2 \\
0\end{array}$ & $\begin{array}{l}3 \\
0\end{array}$ & & $\begin{array}{l}2 \\
0\end{array}$ & & & & & & $\begin{array}{l}1 \\
0\end{array}$ & & \\
\hline 1935-39 & $\begin{array}{l}\text { TD } \\
\text { CD }\end{array}$ & & & & $\begin{array}{l}7 \\
1\end{array}$ & & & $\begin{array}{l}7 \\
1\end{array}$ & $\begin{array}{l}3 \\
0\end{array}$ & & $\begin{array}{l}4 \\
1\end{array}$ & & $\begin{array}{l}2 \\
\mathbf{0}\end{array}$ & $\begin{array}{l}5 \\
2\end{array}$ & $\begin{array}{l}2 \\
0\end{array}$ & & & & & & & \\
\hline $1940-44$ & $\begin{array}{l}\text { TD } \\
\text { CD }\end{array}$ & & & & $\begin{array}{l}3 \\
\mathbf{0}\end{array}$ & $\begin{array}{l}2 \\
\mathbf{0}\end{array}$ & & $\begin{array}{l}3 \\
0\end{array}$ & $\begin{array}{l}3 \\
1\end{array}$ & & $\begin{array}{l}5 \\
1\end{array}$ & $\begin{array}{l}5 \\
1\end{array}$ & & $\begin{array}{l}4 \\
0\end{array}$ & $\begin{array}{l}2 \\
0\end{array}$ & & $\begin{array}{l}1 \\
0\end{array}$ & $\begin{array}{l}1 \\
0\end{array}$ & $\begin{array}{l}1 \\
0\end{array}$ & $\begin{array}{l}3 \\
0\end{array}$ & $\begin{array}{l}1 \\
0\end{array}$ & \\
\hline $1945-49$ & $\begin{array}{l}\text { TD } \\
\text { CD }\end{array}$ & & & & $\begin{array}{l}2 \\
0\end{array}$ & $\begin{array}{l}1 \\
0\end{array}$ & & $\begin{array}{l}4 \\
0\end{array}$ & $\begin{array}{l}1 \\
0\end{array}$ & $\begin{array}{l}2 \\
0\end{array}$ & $\begin{array}{l}6 \\
4\end{array}$ & $\begin{array}{l}1 \\
1\end{array}$ & $\begin{array}{l}1 \\
1\end{array}$ & $\begin{array}{l}2 \\
0\end{array}$ & $\begin{array}{l}3 \\
0\end{array}$ & $\begin{array}{l}2 \\
0\end{array}$ & $\begin{array}{l}6 \\
0\end{array}$ & $\begin{array}{l}6 \\
2\end{array}$ & & & & \\
\hline $1950-54$ & $\begin{array}{l}\text { TD } \\
\text { CD }\end{array}$ & & & & & & & $\begin{array}{l}1 \\
0\end{array}$ & & $\begin{array}{l}1 \\
1\end{array}$ & $\begin{array}{l}9 \\
3\end{array}$ & $\begin{array}{l}3 \\
1\end{array}$ & $\begin{array}{l}1 \\
0\end{array}$ & $\begin{array}{l}5 \\
1\end{array}$ & $\begin{array}{l}4 \\
1\end{array}$ & $\begin{array}{l}3 \\
\mathbf{0}\end{array}$ & $\begin{array}{l}3 \\
1\end{array}$ & & & $\begin{array}{l}1 \\
0\end{array}$ & $\begin{array}{l}2 \\
0\end{array}$ & \\
\hline 1955-59 & $\begin{array}{l}\text { TD } \\
\text { CD }\end{array}$ & & & & & & & $\begin{array}{l}3 \\
0\end{array}$ & $\begin{array}{l}1 \\
0\end{array}$ & $\begin{array}{l}1 \\
0\end{array}$ & $\begin{array}{l}2 \\
1\end{array}$ & $\begin{array}{l}6 \\
4\end{array}$ & $\begin{array}{l}1 \\
0\end{array}$ & $\begin{array}{l}5 \\
3\end{array}$ & & & $\begin{array}{l}6 \\
3\end{array}$ & $\begin{array}{l}3 \\
0\end{array}$ & & $\begin{array}{l}5 \\
0\end{array}$ & $\begin{array}{l}3 \\
0\end{array}$ & \\
\hline $1960-64$ & $\begin{array}{l}\text { TD } \\
\text { CD }\end{array}$ & & & & & & & $\begin{array}{l}1 \\
0\end{array}$ & & & $\begin{array}{l}3 \\
1\end{array}$ & $\begin{array}{l}4 \\
2\end{array}$ & & $\begin{array}{r}13 \\
3\end{array}$ & $\begin{array}{l}4 \\
3\end{array}$ & $\begin{array}{l}4 \\
0\end{array}$ & $\begin{array}{l}9 \\
2\end{array}$ & $\begin{array}{l}3 \\
0\end{array}$ & & $\begin{array}{l}3 \\
0\end{array}$ & $\begin{array}{l}2 \\
0\end{array}$ & \\
\hline $1965-69$ & $\begin{array}{l}\text { TD } \\
\text { CD }\end{array}$ & & & & & & & & & & $\begin{array}{l}3 \\
2\end{array}$ & $\begin{array}{l}3 \\
0\end{array}$ & $\begin{array}{l}3 \\
0\end{array}$ & $\begin{array}{r}15 \\
5\end{array}$ & $\begin{array}{l}7 \\
1\end{array}$ & $\begin{array}{l}1 \\
0\end{array}$ & $\begin{array}{r}16 \\
5\end{array}$ & $\begin{array}{l}9 \\
3\end{array}$ & $\begin{array}{l}1 \\
1\end{array}$ & $\begin{array}{l}5 \\
0\end{array}$ & $\begin{array}{l}6 \\
0\end{array}$ & $\begin{array}{l}3 \\
0\end{array}$ \\
\hline $1970-74$ & $\begin{array}{l}\text { TD } \\
\text { CD }\end{array}$ & & & & & & & & & & & $\begin{array}{l}1 \\
1\end{array}$ & & $\begin{array}{r}11 \\
3\end{array}$ & $\begin{array}{l}1 \\
0\end{array}$ & $\begin{array}{l}3 \\
3\end{array}$ & $\begin{array}{r}14 \\
5\end{array}$ & $\begin{array}{l}6 \\
4\end{array}$ & $\begin{array}{l}2 \\
0\end{array}$ & $\begin{array}{l}6 \\
2\end{array}$ & $\begin{array}{l}3 \\
0\end{array}$ & $\begin{array}{l}1 \\
0\end{array}$ \\
\hline $1975-77$ & $\begin{array}{l}\text { TD } \\
\text { CD }\end{array}$ & & & & & & & & & & & & & $\begin{array}{l}1 \\
0\end{array}$ & & & $\begin{array}{l}4 \\
1\end{array}$ & $\begin{array}{l}1 \\
1\end{array}$ & & $\begin{array}{l}3 \\
0\end{array}$ & $\begin{array}{l}2 \\
0\end{array}$ & \\
\hline
\end{tabular}

TD, total No of deaths; CD, No of cancer deaths; US, BS, Fam, see text. 
TABLE 3 Distribution of deaths of grandmothers of retinoblastoma probands

\begin{tabular}{|c|c|c|c|c|c|c|c|c|c|c|c|c|c|c|c|c|c|c|c|c|c|c|}
\hline \multirow[t]{2}{*}{ Date } & & \multicolumn{3}{|c|}{ Age $20-29$} & \multicolumn{3}{|c|}{$30-39$} & \multicolumn{3}{|c|}{$40-49$} & \multicolumn{3}{|c|}{$50-59$} & \multicolumn{3}{|c|}{$60-69$} & \multicolumn{3}{|c|}{$70-79$} & \multicolumn{3}{|c|}{$\geqslant 80$} \\
\hline & & US & $B S$ & Fam & US & $B S$ & Fam & $U S$ & $B S$ & Fam & US & $B S$ & Fam & US & $B S$ & Fam & US & $B S$ & Fam & $U S$ & $B S$ & Fam \\
\hline 1925-29 & $\begin{array}{l}\text { TD } \\
\text { CD }\end{array}$ & $\begin{array}{l}1 \\
0\end{array}$ & & & & & & & & & & & & & & & & & & & & \\
\hline 1930-34 & $\begin{array}{l}\text { TD } \\
\text { CD }\end{array}$ & $\begin{array}{l}1 \\
0\end{array}$ & & & $\begin{array}{l}2 \\
0\end{array}$ & & & $\begin{array}{l}2 \\
0\end{array}$ & & & $\begin{array}{l}2 \\
0\end{array}$ & 2 & & 2 & & & $\begin{array}{l}1 \\
0\end{array}$ & & & & & \\
\hline 1935-39 & $\begin{array}{l}\text { TD } \\
\text { CD }\end{array}$ & $\begin{array}{l}1 \\
0\end{array}$ & $\begin{array}{l}2 \\
0\end{array}$ & & & $\begin{array}{l}2 \\
0\end{array}$ & & $\begin{array}{l}1 \\
0\end{array}$ & & & $\begin{array}{l}1 \\
0\end{array}$ & & & $\begin{array}{l}1 \\
0\end{array}$ & & & $\begin{array}{l}1 \\
0\end{array}$ & & & & & \\
\hline $1940-44$ & $\begin{array}{l}\text { TD } \\
\text { CD }\end{array}$ & & & & $\begin{array}{l}2 \\
1\end{array}$ & $\begin{array}{l}4 \\
0\end{array}$ & & $\begin{array}{l}2 \\
0\end{array}$ & & & $\begin{array}{l}3 \\
1\end{array}$ & & & $\begin{array}{l}4 \\
0\end{array}$ & $\begin{array}{l}1 \\
0\end{array}$ & & $\begin{array}{l}4 \\
1\end{array}$ & $\begin{array}{l}1 \\
0\end{array}$ & $\begin{array}{l}2 \\
1\end{array}$ & & & \\
\hline $1945-49$ & $\begin{array}{l}\text { TD } \\
\text { CD }\end{array}$ & & & & $\begin{array}{l}1 \\
0\end{array}$ & & & $\begin{array}{l}2 \\
1\end{array}$ & $\begin{array}{l}1 \\
0\end{array}$ & & $\begin{array}{l}1 \\
0\end{array}$ & $\begin{array}{l}1 \\
1\end{array}$ & & $\begin{array}{l}3 \\
1\end{array}$ & $\begin{array}{l}2 \\
0\end{array}$ & & $\begin{array}{l}1 \\
0\end{array}$ & & $\begin{array}{l}2 \\
0\end{array}$ & $\begin{array}{l}1 \\
0\end{array}$ & & \\
\hline $1950-54$ & $\begin{array}{l}\text { TD } \\
\text { CD }\end{array}$ & & & & $\begin{array}{l}1 \\
1\end{array}$ & & & $\begin{array}{l}1 \\
0\end{array}$ & $\begin{array}{l}3 \\
1\end{array}$ & & $\begin{array}{l}5 \\
3\end{array}$ & $\begin{array}{l}2 \\
1\end{array}$ & $\begin{array}{l}1 \\
0\end{array}$ & $\begin{array}{l}6 \\
4\end{array}$ & $\begin{array}{l}2 \\
1\end{array}$ & & $\begin{array}{l}2 \\
0\end{array}$ & & & $\begin{array}{l}2 \\
0\end{array}$ & $\begin{array}{l}2 \\
0\end{array}$ & $\begin{array}{l}1 \\
0\end{array}$ \\
\hline $1955-59$ & $\begin{array}{l}\text { TD } \\
\text { CD }\end{array}$ & & $\begin{array}{l}1 \\
0\end{array}$ & & & & & & 1 & & $\begin{array}{l}5 \\
1\end{array}$ & $\begin{array}{l}2 \\
0\end{array}$ & & $\begin{array}{l}6 \\
3\end{array}$ & $\begin{array}{l}2 \\
1\end{array}$ & $\begin{array}{l}3 \\
2\end{array}$ & $\begin{array}{l}4 \\
0\end{array}$ & $\begin{array}{l}1 \\
1\end{array}$ & & $\begin{array}{l}2 \\
0\end{array}$ & & \\
\hline $1960-64$ & $\begin{array}{l}\text { TD } \\
\text { CD }\end{array}$ & & & & & & & $\begin{array}{l}1 \\
0\end{array}$ & & & $\begin{array}{l}3 \\
0\end{array}$ & $\begin{array}{l}1 \\
0\end{array}$ & & $\begin{array}{l}5 \\
1\end{array}$ & $\begin{array}{l}3 \\
2\end{array}$ & & $\begin{array}{r}11 \\
2\end{array}$ & $\begin{array}{l}4 \\
1\end{array}$ & & $\begin{array}{l}2 \\
0\end{array}$ & 3 & \\
\hline $1965-69$ & $\begin{array}{l}\text { TD } \\
\text { CD }\end{array}$ & & & & & & & & $\begin{array}{l}1 \\
0\end{array}$ & & & $\begin{array}{l}5 \\
3\end{array}$ & & $\begin{array}{l}5 \\
0\end{array}$ & $\begin{array}{l}4 \\
1\end{array}$ & & $\begin{array}{r}11 \\
3\end{array}$ & $\begin{array}{l}3 \\
1\end{array}$ & & $\begin{array}{l}8 \\
1\end{array}$ & $\begin{array}{l}6 \\
1\end{array}$ & \\
\hline 1970-74 & $\begin{array}{l}\text { TD } \\
\text { CD }\end{array}$ & & & & & & & & & & & & $\begin{array}{l}3 \\
2\end{array}$ & $\begin{array}{l}2 \\
0\end{array}$ & $\begin{array}{l}4 \\
2\end{array}$ & & $\begin{array}{r}11 \\
3\end{array}$ & $\begin{array}{l}5 \\
1\end{array}$ & $\begin{array}{l}1 \\
1\end{array}$ & $\begin{array}{l}7 \\
0\end{array}$ & $\begin{array}{l}4 \\
2\end{array}$ & $\begin{array}{l}3 \\
1\end{array}$ \\
\hline 1975-77 & $\begin{array}{l}\text { TD } \\
\text { CD }\end{array}$ & & & & & & & & & & & & & $\begin{array}{l}1 \\
0\end{array}$ & $\begin{array}{l}1 \\
1\end{array}$ & & $\begin{array}{l}3 \\
1\end{array}$ & $\begin{array}{l}4 \\
0\end{array}$ & $\begin{array}{l}1 \\
0\end{array}$ & $\begin{array}{l}6 \\
1\end{array}$ & 1 & 2 \\
\hline
\end{tabular}

TD, total No of deaths; CD, No of cancer deaths; US, BS, Fam, see text.

\section{Results}

Tables 2 and 3 give the total number of deaths and the number of deaths by cancer, respectively, for grandfathers and grandmothers, for each age-period group, separately for unilateral sporadic cases (US), bilateral sporadic cases (BS), and familial cases (Fam).

Among the 621 deaths, 110.6 cancers were expected and 148 were observed. This excess is highly significant $\left(10^{-4}>\mathrm{p}>10^{-5}\right)$. Before analysing these results more precisely, we considered whether this excess might be the result of a higher percentage of replies from families in which there were multiple cases of cancer. We compared the results obtained with the methods of data collection. In 102 cases, all the information had been obtained by direct interview. In 52 of these cases, the parents had been interviewed at the time the child was admitted to hospital (group 1). In 50 cases, they had been inter-

TABLE 4 Expected and observed numbers of cancer deaths in grandparents of retinoblastoma patients according to method of data collection

\begin{tabular}{llll}
\hline & $\begin{array}{l}\text { Interview at time } \\
\text { of admission } \\
\text { to hospital }\end{array}$ & $\begin{array}{l}\text { Interview after } \\
\text { agreement of } \\
\text { parents }\end{array}$ & Questionnaire \\
\hline $\begin{array}{l}\text { Total No of } \\
\text { deaths }\end{array}$ & 39 & 133 & 449 \\
$\begin{array}{l}\text { No of cancer } \\
\text { deaths } \\
\text { Expected }\end{array}$ & 8.4 & 23.6 & 78.6 \\
$\begin{array}{l}\text { Observed } 16 \\
\text { Probability* } 10^{-2}>\mathrm{p}>10^{-3}\end{array}$ & $\begin{array}{c}41 \\
10^{-4}>\mathrm{p}>10^{-5}\end{array}$ & $\begin{array}{l}91 \\
0.07>\mathrm{p}>0.06\end{array}$ \\
\hline Right tailed test. & &
\end{tabular}

Right tailed test. viewed in a genetic centre or at their home after they had given their agreement (group 2). In the 206 other cases (group 3), the information had been obtained either by questionnaire (119 cases) or by interview, but completed by questionnaire (87 cases). Selection of families with cancer may occur in groups 2 and 3 but not in group 1 , so if the excess of cancer is partly the result of this bias, it should be less important in group 1 than in the other two groups. Table 4 gives the expected and observed numbers of cancer deaths in the three groups. The excess is not greater in groups 2 and 3 than in group 1, proving the absence of such a bias. The excess is smaller in group 3, suggesting that the number of cancer deaths is underestimated in this group, probably because of the excess of imprecise answers, such as 'liver disease', in this group compared to the other two groups. (Imprecise answers have been counted as not cancer, in order to avoid an overestimation of the number of cancer deaths.)

TABLE 5 Expected and observed numbers of cancer deaths in grandparents of retinoblastoma patients according to type

\begin{tabular}{|c|c|c|c|}
\hline & $\begin{array}{l}\text { Unilateral } \\
\text { sporadic }\end{array}$ & $\begin{array}{l}\text { Bilateral } \\
\text { sporadic }\end{array}$ & Familial \\
\hline $\begin{array}{l}\text { Total No of } \\
\text { deaths } \\
\text { No of cancer } \\
\text { deaths }\end{array}$ & 375 & 191 & 55 \\
\hline $\begin{array}{l}\text { Expected } \\
\text { Observed } \\
\text { Probability* }\end{array}$ & $\begin{array}{l}61 \cdot 6 \\
81 \\
10^{-2}>p>10^{-3}\end{array}$ & $\begin{array}{l}34 \cdot 5 \\
51 \\
10^{-3}>p>10^{-4}\end{array}$ & $\begin{array}{l}10.5 \\
16 \\
0.04>p>0.03\end{array}$ \\
\hline
\end{tabular}

*Right tailed test. 
Table 5 shows the excess found in all types of retinoblastoma. The excess exists in both sexes, as shown in table 6 , but seems to affect only deaths after 50 .

In sporadic cases, we examined the families where at least one grandparent was dead on each side of the pedigree and at least one of them died of cancer. We calculated in each family the respective probabilities that cancer occurred in both sides and in only one side of the pedigree, using French statistics. Summing over all families, we obtained the expected numbers of families of each type and compared them to the observed numbers. The results are given in table 7. In unilateral cases, there is an excess of families where cancer deaths occurred on both sides of the pedigree $(p=0.004$, binomial distribution), but not in bilateral cases.

In familial cases, the expected and observed numbers of cancer deaths were compared according to the manifestation in the proband (table 8), to the pedigree pattern (table 9), and to the possibility that

TABLE 6 Expected and observed numbers of cancer deaths in grandparents of retinoblastoma patients according to sex and age.

\begin{tabular}{llllcl}
\hline Sex & \multirow{2}{*}{ No of deaths } & \multicolumn{3}{l}{ Age } & \\
\cline { 4 - 6 } & & & $<50$ & $\geqslant 50$ & Total \\
\hline \multirow{4}{*}{ Male } & Total & & 58 & 313 & 371 \\
& Cancer & Expected & $3 \cdot 8$ & $60 \cdot 5$ & $64 \cdot 3$ \\
& & Observed & 4 & 81 & 85 \\
Female & Total & & 33 & 217 & 250 \\
& Cancer & Expected & $4 \cdot 2$ & $42 \cdot 1$ & $46 \cdot 3$ \\
& & Observed & 5 & 58 & 63 \\
Total & Total & & 91 & 530 & 621 \\
& Cancer & Expected & $8 \cdot 0$ & $102 \cdot 6$ & $110 \cdot 6$ \\
& & Observed & 9 & 139 & 148 \\
\hline
\end{tabular}

TABLE 7 Distribution of cancer deaths in grandparents of sporadic cases according to side of pedigree

\begin{tabular}{llll}
\hline Probands & No of families & \multicolumn{2}{l}{ Cancer deaths in } \\
\cline { 3 - 4 } & & Brandparents \\
\cline { 3 - 4 } & & $3 \cdot 5$ & One sides \\
\hline Bilateral & Expected & 3 & $22 \cdot 5$ \\
& Observed & 3 & 23 \\
Unilateral & Expected & $4 \cdot 9$ & $30 \cdot 1$ \\
& Observed & 12 & 23 \\
\hline
\end{tabular}

TABLE 8 Expected and observed numbers of cancer deaths in grandparents of familial cases according to manifestation in proband

\begin{tabular}{lll}
\hline & Bilateral & Unilateral \\
\hline Total No of deaths & 17 & 38 \\
No of cancer deaths & & \\
Expected & 4.5 & 6.0 \\
Observed & 5 & 11 \\
Probability* & $0.5>p>0.4$ & $0.04>p>0.03$ \\
\hline
\end{tabular}

*Right tailed binomial
TABLE 9 Expected and observed numbers of cancer deaths in grandparents of familial cases according to pedigree pattern

\begin{tabular}{|c|c|c|c|}
\hline & $\begin{array}{l}\text { Affected parent } \\
\pm \text { affected } \\
\text { sib }(s)\end{array}$ & $\begin{array}{l}\text { Affected sibs } \\
\text { only }\end{array}$ & $\begin{array}{l}\text { More distant } \\
\text { affected } \\
\text { relative }(s)\end{array}$ \\
\hline $\begin{array}{l}\text { Total No of } \\
\text { deaths } \\
\text { No of cancer } \\
\text { deaths }\end{array}$ & 11 & 19 & 25 \\
\hline $\begin{array}{l}\text { Expected } \\
\text { Observed } \\
\text { Probability* }\end{array}$ & $\begin{array}{l}2.6 \\
3 \\
0.6>p>0.5\end{array}$ & $\begin{array}{l}3.6 \\
4 \\
0.6>p>0.5\end{array}$ & $\begin{array}{l}4.3 \\
9 \\
0.02>p>0.01\end{array}$ \\
\hline
\end{tabular}

TABLE 10 Expected and observed numbers of cancer deaths in grandparents of familial cases according to possibility of being gene carriers

\begin{tabular}{|c|c|c|c|c|}
\hline & $\begin{array}{l}\text { Group } \\
1\end{array}$ & 2 & 3 & 4 \\
\hline $\begin{array}{l}\text { Total No of deaths } \\
\text { No of cancer deaths }\end{array}$ & 14 & 7 & 31 & 3 \\
\hline $\begin{array}{l}\text { Expected } \\
\text { Observed } \\
\text { Probability† }\end{array}$ & $\begin{array}{l}2 \cdot 8 \\
4 \\
0 \cdot 4>p> \\
0 \cdot 3\end{array}$ & $\begin{array}{l}1 \cdot 9 \\
3 \\
0 \cdot 3>p> \\
0 \cdot 2\end{array}$ & $\begin{array}{l}5 \cdot 1 \\
6 \\
0 \cdot 5>p> \\
0 \cdot 4\end{array}$ & $\begin{array}{l}0.7 \\
3 \\
0.02>p \\
0.01\end{array}$ \\
\hline
\end{tabular}

*See text.

†Right tailed binomial

the grandparents were gene carriers (table 10). The exact probability of being a gene carrier cannot be computed easily except in extreme cases. A grand $\overrightarrow{\vec{O}}$ parent who is not situated on the same side of the pedigree as the affected relative(s) of the proban cannot be a gene carrier (group 1) and a grandparen? who is on the pathway of relationship between the affected relative(s) and the proband, or is himselP affected, is certainly a gene carrier (group 4). WE separated the other grandparents into two groups.

Group 2 consisted of grandparents who are the parents of an affected parent of the proband, this parent being the first affected in the family. Most of them are not gene carriers, but a little less than one ing two produced a mutated gamete.

Group 3 consisted of grandparents of severals affected sibs with unaffected parents, or grandparents situated on the same side of the pedigree as the affected relative(s). They may be gene carriers.

Tables 8, 9, and 10 show that an analysis of familial cases is difficult because the number of deaths is small when broken down into differen categories. However, the following may be noted.

The excess of cancer deaths is significant when the proband is unilaterally affected but not when he if bilaterally affected.

It is also significant when the retinoblastoma gene has been transmitted through one or severab unaffected relatives and not in other cases. 
TABLE 11 Sites of cancers in grandparents of retinoblastoma patients

\begin{tabular}{lcc}
\hline Organs & Expected & Observed \\
\hline Mouth, face & $3 \cdot 1$ & 4 \\
Oesophagus & $6 \cdot 9$ & 7 \\
Stomach & $9 \cdot 9$ & 15 \\
Intestine & $15 \cdot 8$ & 16 \\
Liver (primary), hepatic ducts & $2 \cdot 4$ & 1 \\
Pancreas & $4 \cdot 6$ & 4 \\
Digestive system (non-specific) & $3 \cdot 3$ & 2 \\
Larynx, pharynx & $9 \cdot 8$ & 13 \\
Lungs, respiratory system & $18 \cdot 7$ & 20 \\
Bones & $1 \cdot 1$ & 4 \\
Skin & $1 \cdot 4$ & 0 \\
Breast & $9 \cdot 0$ & 7 \\
Female genital organs & $7 \cdot 3$ & 4 \\
Male genital organs & $5 \cdot 5$ & 2 \\
Bladder, urinary tract & $5 \cdot 4$ & 2 \\
Eye, brain, nervous system & $1 \cdot 7$ & 3 \\
Endocrine glands & $0 \cdot 6$ & 0 \\
Lymphosarcoma, reticulum cell sarcoma & $1 \cdot 1$ & 1 \\
Hodgkin's and other lymphatic tumours & $1 \cdot 0$ & 2 \\
Leukaemias and other myeloproliferative & & $5 \cdot 4$ \\
disorders & 7 \\
\hline
\end{tabular}

As to the possibility of being gene carriers, it is significant only when the grandparent is definitely a gene carrier in spite of the small number of deaths. Among the three grandparents, two were on the pathway of relationship between distant relatives and one himself had unilateral retinoblastoma.

The different sites of cancer are listed in table 11 except for 19 cases where it was not specified and 15 cases of liver cancer not specified as primary or secondary. There is a wide variety of sites. The figures expected for the different sites were calculated for each age-sex group using the proportions in the French population of 1975 . The distributions are not different among grandparents of retinoblastoma patients and in the general population $\left(\chi_{11}^{2}=12 \cdot 91\right.$, after gathering small groups).

\section{Discussion}

A major question is whether the highly significant differences are the result of bias or not. We did not find a greater excess of cancer deaths in the groups where selection of families with cancer could have occurred than in the group where this type of selection was absent. However, we cannot eliminate another type of bias, resulting from the fact that data were not collected in the same way for grandparents of patients and controls. For this, it would be necessary for our results to be checked in an unbiased way, for instance in a country where death certificates of named people can be traced. If the excess is not the result of such a bias, the following may be discussed.

The occurrence of second primary cancers in children with retinoblastoma has been attributed to the retinoblastoma gene. ${ }^{45}$ According to this hypothesis, one would expect a higher proportion of cancer deaths among relatives who may be gene carriers than among those who probably are not.

The probability that grandparents of sporadic cases may be gene carriers can be approximately estimated from the recurrence risks in sibs. In bilateral cases, we estimated 10 to $20 \%$ as the proportion of bilateral sporadic cases which are not the result of fresh mutations in one of the parents. ${ }^{13}$ A new germ cell mutation may also have occurred in a grandparent, so the proportion of gene carriers among grandparents is less than 2.5 to $5 \%$ and cannot reasonably explain the increase in susceptibility to cancer. In unilateral sporadic cases, the recurrence risk in sibs is 0.5 to $1 \%$ which gives a proportion of carrier grandparents less than $1 \%$, making this explanation still more unlikely.

This suggests that the factor increasing the risk of cancer in grandparents of children with retinoblastoma is different from the gene of retinoblastoma but may have some relationship with it.

According to the mutation hypothesis, this factor of susceptibility to cancer (FSC) could favour the occurrence of tumours by increasing the mutation rate in several tissues including retina and germ cells. As it is found in several members of the same family, it could be inherited, but it could also be because of common environment. The excess of cancer deaths occurring in both sides of the family in unilateral sporadic cases could mean that this factor is inherited with additive effects. However, one does not understand why this excess on both sides is not found in bilateral cases, unless this factor acts only on the first mutation. In fact, in most bilateral sporadic cases, the first mutation occurs in the germ cells of one of the parents, whereas in unilateral cases this mutation occurs in the retinal cells of the proband himself. Using such a hypothesis, one would expect, among couples of grandparents of bilateral sporadic cases where at least one was dead of cancer, an excess of couples in which both grandfather and grandmother died of cancer. In bilateral cases, there were 29 such couples and in six of them both grandparents died of cancer, whereas 3.0 were expected; this excess is not far from significance ( $p=0 \cdot 07$, right-tailed binomial). We did not find such an excess in unilateral cases: in four of the 33 couples both grandparents died of cancer, whereas 3.0 were expected. However, the results between unilateral and bilateral cases are not different enough to permit definite conclusions.

There is another indirect argument for the FSC acting only on the first mutation. A difference of expressivity and penetrance has been noted in hereditary cases according to the manifestation in 
the carrier parent..$^{15} 16$ Offspring of bilateral cases have a higher probability of being affected and, when affected, a higher probability of bilaterality than the offspring of hereditary unilateral cases, and still higher than the offspring of unaffected carriers. According to the mutation theory, one could explain such a difference if the rate of the second (somatic) mutation were higher in bilateral cases than in unilateral cases and unaffected carriers. The correlation between expressivity and penetrance would be a consequence of the correlation between mutation rates of parent and offspring, as a result of the existence of an inherited 'mutator factor'. If this hypothetical 'mutator factor' were the same as the FSC found in grandparents, one would expect in familial cases a higher frequency of cancer among grandparents of bilateral cases and of cases from families with a high degree of penetrance than among grandparents of unilateral cases and of cases from families with several unaffected carriers, which is not found (tables 8, 9). We may conclude that the FSC has apparently no effect on the rate of the second mutation and cannot explain the differences of expressivity and penetrance among gene carriers.

Then, if the FSC acts only on the rate of the first mutation, we cannot expect an increase in cancer deaths among the familial cases who have inherited this mutation. This is, however, found, in particular when distant relatives are affected (table 9). $\mathrm{Neel}^{17}$ and Knudson ${ }^{1}$ explained these families by the phenomenon of delayed mutation proposed by Auerbach..$^{18}$ A premutated allele could be transmitted through one or several generations and then changed into a mutated allele (what Herrmann ${ }^{19}$ calls telomutation) in the retinal cells of a subject who would have retinoblastoma, or in his germ cell, producing affected offspring. If such a mechanism exists, which seems highly probable, the increase of cancer deaths in these particular families could well be explained if the FSC acts not only on the mutation rate but also on the telomutation rate, mechanisms which should have some common aetiology. This would also explain the excess of cancer deaths when the proband is unilaterally affected, because most unilateral familial cases belong to these families.

We have not elucidated whether the FSC was the same in retinoblastoma patients and in their grandparents. Several arguments tend to weaken this possibility.

It is striking that we observed an increase in all types of cancer and not in a specific type. This is not a common observation, though examples of familial occurrences of neoplasms of dissimilar types, including childhood cancers, have been published. ${ }^{20}$ Other primary tumours found in patients with retinoblastoma seem to be more specific; in particular there is a high frequency of femoral osteogenio sarcoma. In our sample of grandparents, we found: only a slight excess of bone cancer (table 11) coms pared to other cancers $(p=0.027$, right taile $\phi$ binomial). The fact that osteogenic sarcoma is more frequent among patients than among grandparentsf may be age-related, since bone cancer is relativel $\Phi$ more frequent in childhood and adolescences However, this argument does not seem to explain. adequately the discordance in specificity of canceP between patients and grandparents.

The second argument is that second primary cancers are found mostly in bilateral and in familia cases. $^{45}$ If these cancers were the result of the FSE transmitted from their grandparents, the highes $\vec{N}$ incidence should be found in patients in whom the first mutation occurred, that is unilateral sporadier cases.

Thus, the best explanation of cancers occurring inpatients is the pleiotropic effect of either the retino? blastoma gene, as suggested by the authors, or of a gene which would favour the manifestation ofo retinoblastoma in a gene carrier and produce othepo cancers.

We tried to explain our results, using Knudson'sO hypothesis of two mutational steps. Other models have been proposed: Herrmann ${ }^{19}$ suggested that alp pedigree patterns could be explained by the phenomenon of delayed mutation. Although these models do not exclude each other, there are severa $\vec{B}$ points of conflict; in particular, Herrmann thinks if unnecessary to postulate a second somatic mutation? Matsunaga $^{21}$ rejected both models and he concluded that there was little need to postulate delayed mutation, that only one mutation was involved, an $\bar{p}$ that both penetrance and expressivity in a gene carries could be defined as a variable determined by genetic and environmental factors, what he called hose resistance.

Since we found that the increase in cancer deaths in grandparents of patients was not the result of the retinoblastoma gene, but of a factor which probably. increases the rate of the first (or single) mutation, wo cannot argue for or against any of these three hypotheses, except that the phenomenon of delayed mutation is very probable in some hereditary cases $\omega$

We thank Drs F Serville (Bordeaux), B Le Mareco (Rennes), and C Stoll (Strasbourg) for co-operation with the study, and Dr S Berenberg (Internationaf Children Centre) for revision of the manuscript.

\section{References}

1 Knudson AG. Mutation and cancer: statistical study retinoblastoma. Proc Nat Acad Sci USA 1971;68:820-3. 
2 Sagerman R, Cassady JR, Tretter P, Ellsworth RM. Radiation induced neoplasia following external beam therapy for children with retinoblastoma. $A J R 1969$; 105:529-35.

3 Jensen RD, Miller RW. Retinoblastoma: epidemiologic characteristics. N Engl J Med 1971;285:307-11.

4 Strong LC, Knudson AG. Second cancers in retinoblastoma. Lancet 1973;2:1086.

${ }^{5}$ Kitchin FD, Ellsworth RM. Pleiotropic effects of the gene for retinoblastoma. J Med Genet 1974;11:244-6.

6 Abramson DH, Ellsworth RM, Zimmerman LE. Nonocular cancer in retinoblastoma survivors. Trans Am Acad Ophthalmol Otolaryngol 1976;81:454-7.

7 Weichselbaum RR, Nove J, Little JB. Skin fibroblasts from a D-deletion type retinoblastoma patient are abnormally X-ray sensitive. Nature 1977;266:726-7.

8 Weichselbaum RR, Nove J, Little JB. X-ray sensitivity of diploid fibroblasts from patients with hereditary or sporadic retinoblastoma. Proc Natl Acad Sci USA $1978 ; 75: 3962-4$.

9 Schimke RN, Lowman JT, Cowan GAB. Retinoblastoma and osteogenic sarcoma in siblings. Cancer 1974;34: 2077-9.

10 Gordon H. Family studies in retinoblastoma. Birth Defects $1974 ; 10(10): 185-90$.

11 Chan H, Pratt CB. A new familial cancer syndrome? A spectrum of malignant and benign tumors including retinoblastoma, carcinoma of the bladder and other genitourinary tumors, thyroid adenoma and probable case of multifocal osteosarcoma. J Natl Cancer Inst 1977;58:205-7.

12 Fedrick J, Baldwin JA. Incidence of cancer in relatives of children with retinoblastoma. $B r M e d J 1978 ; 1: 83-4$.
13 Briard-Guillemot ML, Bonaïti-Pellié C, Feingold J, Frézal J. Etude génétique du rétinoblastome. Humangenetik 1974;24:271-84.

14 Swift M, Cohen J, Pinkham RA. A maximum-likelihood method for estimating the disease predisposition in heterozygotes. Am J Hum Genet 1974;26:304-17.

15 Ellsworth RM. The practical management of retinoblastoma. Trans Am Ophthalmol Soc 1969;67:462-534.

16 Matsunaga E. Hereditary retinoblastoma: penetrance, expressivity and age of onset. Hum Genet 1976;33:1-15.

17 Neel JV. Mutations in the human population. In: Burdette WJ, ed. Methodology in human genetics. San Francisco: Holden-Day, 1962:203-6.

18 Auerbach C. A possible case of delayed mutation in man. Ann Hum Genet 1956;20:266-9.

19 Herrmann J. Delayed mutation model: carotid body tumors and retinoblastoma. In: Mulvihill JJ, Miller RW, Fraumeni JF, eds. Genetics of human cancer. New York: Raven Press, 1977:417-38.

20 Fraumeni JF. Clinical patterns of familial cancer. In: Mulvihill JJ, Miller RW, Fraumeni JF, eds. Genetics of human cancer. New York: Raven Press, 1977:223-33.

21 Matsunaga E. Hereditary retinoblastoma: delayed mutation or host resistance? Am J Hum Genet 1978;30: 406-24.

Requests for reprints to Dr C Bonaïti-Pellié, Groupe de Recherches de Génétique Epidémiologique, INSERM, Château de Longchamp, Bois de Boulogne, 75016 Paris, France. 